\title{
Online Political Debate: Motivating Factors and Impact on Political Engagement
}

\author{
Asbjørn Følstad and Marika Lüders \\ SINTEF \\ PB 124, Blindern \\ 0314 Oslo, Norway \\ \{asbjorn.folstad, marika.lueders\}@sintef.no
}

\begin{abstract}
Online political debate is increasing in importance, both as a real world phenomenon and as an object of scientific study. We present a survey study exploring people's motivations for engaging in online political debate and how such debate may impact their general political engagement. The survey was conducted among 90 participants of an online environment for political debate hosted by one of the main Norwegian political parties. We found four motivational factors with relevance for participation in online political debate: engaging topic, want to contribute, frustration, and reciprocal learning. Sixtyfour per cent of the participants answered that the online environment for political debate could make them more politically engaged. These participants reported that such an increase in political engagement could be due to the online environment providing a sense of influence, access to political debate, a means for getting updated, a lowered threshold for participation, motivating local political engagement, and awareness concerning political events.
\end{abstract}

\section{Introduction}

Political debate is increasingly conducted online. This trend has been welcomed with enthusiasm as it has been assumed that such political debate may lower the threshold for participation, increase citizen involvement, and, in consequence, strengthen democracy [8]. The enthusiasm has seemed warranted as citizens do make use of online arenas for political debate to share their opinions and engage themselves politically [5; 7]. It is suggested that online political debate may be beneficial to public involvement in policymaking [11]. Also, it has been suggested that online arenas for political debate may serve as a public sphere supporting rational-critical discourse among its participants [3], though this has been severely criticized [11].

A range of studies have been conducted to characterize those that engage in online political debate, for example in terms of gender, age, and education. Also, efforts have been made to assess the quality of such online debate [11]. The contribution of this study is to provide insight into the motivation of those engaging in online political debate and the perceived impact of such debate on the debaters' political engagement. Thus, this study extends the current knowledge of online political debate as it provides knowledge on how such political debate is perceived from the 
perspective of those who engage in it. Furthermore, it suggests how online political debate may strengthen the participants' general political engagement; the latter being a needed addition to the current literature on the correlation between online and offline political engagement $[1 ; 13]$.

The remainder of the paper is structured as follows: first we provide an overview of previous work. Then we formalize the research questions and present our research method, followed by a presentation of the results of our study. Finally, we discuss the results, their implications, and the study limitations, as well as suggest future work.

\section{Previous Work}

\subsection{Online Political Participation}

Political participation is hardly an unambiguous term in the scientific literature. Teorell [12] distinguished between responsive, participatory and deliberative models of democracy. Voting and participation in election campaigns are key aspects of a responsive democratic model [14]. Taking part in decision-making processes is at the core of a participatory model [16]. Participating in the political opinion formation is central to a deliberative model [12].

Participatory and deliberative democracy depends on debate and dialogue between citizens. Significant participatory divides have been found concerning gender and education, with males being more active in online political debates, and with educational levels correlating with online political participation $[11 ; 15]$. Yet, in multiple regression analyses, demographic variables (such as gender and age) have been found to explain far less of the variance in online political participation than factors associated with political engagement in general [13].

Individuals' general political interest, offline political engagement, and civic engagement may be better predictors of online political participation than mere demographic variables. Vesnic-Alujevic [15], in a survey study among citizens using the European parliament Facebook pages, found that online political participation correlated strongly with political interest. Likewise, Conroy, Feezell, and Guerrero [1] found a strong correlation between online and offline political engagement in their study of political Facebook groups. De Zúñiga, Jung, and Valenzuela [18] found strong correlations between online political engagement, offline political participation, civic engagement, and the use of social networking sites for news. An experimental study by Min [9] showed that online deliberation may increase the participants' sense of political efficacy and willingness to participate in politics.

Motivated by the promise that online political debate, adhering to the principles of deliberative democracy [12], may strengthen the public sphere, several studies have analysed the quality of such debate. Stromer-Galley and Wichowski [11] summarized this literature, and concluded that "online political debate, created by and for citizens left to their own devices tends not to produce high-quality discussions" [ibid., p. 180]. However, the quality of the discussion, that is, the discussion's adherence to the principles of deliberative democracy, may be higher for debates involving both ordinary citizens and politicians [ibid., p. 179]. Also, the design of the online 
environment for political debate may affect the quality of the discussions; higher quality discussions are found in online environments such as blogs that motivate more contemplative comments rather than a speedy exchange of messages [ibid., p. 178].

\subsection{Online Debate Connecting Citizens and Politicians}

It is noteworthy that the involvement of politicians in online political debate among citizens may improve the quality of the debate. As politicians are elected to represent citizens, they also need to listen to the opinions of the same citizens [4; 17]. Furthermore, politicians listening to, and debating with, ordinary citizens may strengthen the involvement of citizens in policymaking. Stromer-Galley and Wichowski suggest that online discussions "hosted by government agencies or policymakers, enact democracy by situating citizens as agents within the policymaking process" [11, p. 182].

The possible use of online political debate as a means to involve citizens in policymaking may be a way to implement Dahl's [3] characteristic of democratic participation, where all citizens should have the same opportunity to set political agendas and influence political decision-making. Furthermore, online political debate involving ordinary citizens and politicians could have an added democratic value as it may strengthen the openness of political processes [10].

\section{$3 \quad$ Research Questions}

Our research questions are designed to fill what we perceive as two gaps in the current knowledge on online political debate: the motivation for participating in such debates and the impact of such participation on the debaters' political engagement. Two research questions were formulated.

\section{RQ1: Which factors motivate participation in online political debate?}

The current literature provides ample insight into the characteristics of online political debaters. However, the current knowledge on motivational factors is limited. Extending this knowledge is important as it may help us improve the online environments for such debates, as well as understand the role such debates may have in society.

RQ2: How may participation in online political debate impact the general political engagement of the debaters?

From the current literature we know that the tendency to participate in online political debate is closely associated with political engagement in general. However, we find that there is a lack of knowledge concerning how online political debate may come to affect such general political engagement. Extending our knowledge on this issue is relevant both for understanding the role of online political engagement for the individual debater as well as to set up political debate so as to increase general political engagement in the population. 
As the literature suggests that the quality of online political debate may be positively affected by involving both politicians and ordinary citizens, we wanted to investigate our research questions in a context where both these groups participated; this to prevent our findings from being unduly biased by the participants' perception of the online political debate as of low quality.

Furthermore, we wanted to investigate our research questions in an online environment promoting contemplative comments rather than a fast exchange of messages, also for the purpose of controlling against low-quality political debate.

\section{Method}

To gain in-depth understanding of online debaters' motivation, and the impact of such debate on general political engagement, this study was conducted in the context of a single case: an online environment for political debate run by one of the main political parties in Norway.

We wanted to gather data from a relatively large number of participants. Consequently, we decided to conduct an online questionnaire survey. As we wanted the study to be exploratory, we included questionnaire items with free-text answers to gather qualitative data.

\subsection{The Case}

The case was an online environment for political debate hosted by one of the main political parties in Norway. The environment was divided into sections concerning specific topics (such as education, health, employment), specific parts of the party organization (local and higher level party bodies), and blogs for individual politicians.

The online environment was set up to foster deliberative dialogue involving central party members / politicians, peripheral party members, and politically interested citizens who are not members of the party organization. The overall design of the online environment was a portal structure including a number of blogs for specific topics or parts of the party organization. In the separate blogs, discussions were organized as threads following an introductory text. The comment field was located below the discussion thread, to motivate the participants to read others' comments before posting their own. Upon posting a comment, the online debater by default was set to follow the discussion, and notified by e-mail when new comments were posted. The online debaters had to $\log$ in to comment, either as a user of the online environment or through their Facebook or Twitter accounts. The vast majority of debaters participated in their own full name.

\subsection{The Participants and Recruitment Process}

The participants were selected on the basis of their participation in four sections of the online environment; three thematic sections (foreign affairs, education, and employment) and a section serving as the blog for the party leader. In total, 464 
persons had made one or more comments in the four sections during a given two month period in 2010; 87 in the three thematic sections, the others in the party leader blog only. Those that had commented in the three thematic sections, or that had made two or more comments in the party leader blog, were invited. Furthermore, among those that had made only one comment in the party leader blog, 40 were randomly selected. We did not invite persons that had published blog posts (in addition to comments) in the online environment, as we assumed these to be closer to the central party administration. Furthermore, we did not invite persons that had logged in with Twitter or Facebook accounts, as we wanted our participants to be regular visitors of the online environment. These filters excluded 48 of the 464 commenters.

In total we invited 204 persons to participate in the study by invitations sent through the internal messaging system of the studied online environment. Of these, 90 responded to the invitation (44\%). For the purpose of anonymity, no couplings were made in the data set between (a) the debaters and content in the studied online environment and (b) the participants' questionnaire responses.

\subsection{The Questionnaire}

The questionnaire contained 17 questions on demographics, the participants' use of social media, the participants' use of the studied online environment, their motivation for providing comments in the studied online environment, the impact of their online participation on their general political engagement, their experience of the online environment, and suggested changes for the online environment. Due to limited general interest, the findings concerning the latter theme are not presented.

\subsection{The Analysis Process}

The participants' free-text responses concerning their experience of the studied environment, their motivation for commenting, and the impact of their online participation, were subjected to thematic analysis [6]. For each of these questions, an initial set of coding categories was established after the first reading of the comments. The initial categories were then refined following pilot coding. After having established a stable set of coding categories, all comments were coded. Following this, the comments within each coding category were subjected to a second round of analysis for detailed findings.

\section{$5 \quad$ Results}

\subsection{The Participants}

The average age of the participants was 51 years $(S D=13, \min =22, \max =83)$. Sixty-three per cent were male. Nearly half of the participants $(44 \%)$ had used the studied online environment for a year or more. The participants were also active in other social media; $73 \%$ reported that they were regular users of Facebook, $21 \%$ were regular users of Twitter. 
The majority of the participants were members of a political party; $30 \%$ reported that they were active members, $27 \%$ were passive members. About one-sixth $(17 \%)$ reported participating in political meetings.

Upon being asked about their experience of the studied online environment, the most prominent themes were statements on satisfaction (16 comments in this category) and critique of the discussions (nine comments). Statements on satisfaction concerned various aspects of the online environment and the way it was run. The critique of the discussions in particular concerned disrespectful treatment of other participants, varying quality in the comments, and difficulties in getting an overview of discussions; the latter having the consequence that themes were seen as repeated multiple times in the same discussion thread.

\subsection{Which Factors Motivate Participation in Online Political Debate?}

The participants were asked to explicate why they had commented in the studied online environment. The participants' answers were found to reflect four overall motivations:

1. Engaging topic (32\%). These participants reported being engaged by the topic under discussion and/or having strong opinions. Several provided details on the actual topic of interest.

2. Want to contribute (19\%). These participants reported that they had knowledge or experience that they found to be a needed or useful addition to an on-going debate. They typically also reported a desire for their opinion to have some kind of impact.

3. Frustration (12\%). These participants typically reported anger or frustration concerning general societal or political issues. Three of these also aired frustration concerning the debate in the studied online environment.

4. Reciprocal learning (2\%). Two of the participants reported that they found the studied online environment to be an arena for learning.

See Fehler! Verweisquelle konnte nicht gefunden werden. for examples of participant reports concerning motivational factors.

Of relevance to the question on motivation, we found that $38 \%$ of the participants voiced a general wish for even more engagement on the part of politicians in the studied online environment. This was not the topic of any of the questions in the questionnaire, but something that was reported in response to several of the free-text questions.

In particular, the participants wanted feedback from central party members and politicians in the form of comments in the online discussions, clarity concerning the impact of the participants' comments, and clarifications concerning whom from the party organization one may expect to respond to comments. 
Table 1. Example participant comments concerning their motivation for commenting in the studied online environment for political debate

\begin{tabular}{|c|c|}
\hline Theme & Example comments (translated from Norwegian) \\
\hline \multirow[t]{2}{*}{$\begin{array}{l}\text { 1. Engaging } \\
\text { topic }\end{array}$} & $\begin{array}{l}\text { It was something that caught my interest. Issues that I have } \\
\text { experienced or will experience myself. }\end{array}$ \\
\hline & $\begin{array}{l}\text { I am very interested in questions on the politics of drug abuse. I } \\
\text { see a connection between drug addiction and sick leave, crime } \\
\text { and health in general. }\end{array}$ \\
\hline \multirow[t]{2}{*}{$\begin{array}{l}\text { 2. Want to } \\
\text { contribute }\end{array}$} & $\begin{array}{l}\text { I disagreed with the post starting this discussion, and feel that I } \\
\text { have both the competency and the engagement. }\end{array}$ \\
\hline & $\begin{array}{l}\text { Disagree with many of the comments on the causes for sick } \\
\text { leave, and wanted to present my point of view. }\end{array}$ \\
\hline \multirow[t]{2}{*}{ 3. Frustration } & $\begin{array}{l}\text { I commented out of frustration following this year's election and } \\
\text { the subsequent unfulfilled promises concerning students }[. . .]\end{array}$ \\
\hline & I am annoyed concerning the sick leave discussion. \\
\hline \multirow[t]{2}{*}{$\begin{array}{l}\text { 4. Reciprocal } \\
\text { learning }\end{array}$} & $\begin{array}{l}\text { I look at the comments as introductions or replies in a } \\
\text { knowledge debate where the goal is to reciprocally learn and } \\
\text { develops one's own position and opinion in interplay with } \\
\text { politically interested people. }\end{array}$ \\
\hline & $\begin{array}{l}\text { Interesting and sensible debates are pleasant and instructive to } \\
\text { participate in. }\end{array}$ \\
\hline
\end{tabular}

\subsection{How May Participation in Online Political Debate Impact the Political Engagement of the Debaters?}

The participants were asked whether they thought the studied online environment could affect the strength of their political engagement. Sixty-four per cent answered that the studied online environment could make them more politically engaged, $31 \%$ answered that it had no effect, $5 \%$ answered that it could make them less politically active.

The participants who answered that the online environment could make them more politically active were asked, in a separate question, to report in free-text on how the environment could have this effect. The other participants were not asked this question. The thematic analysis yielded six answer categories:

1. Sense of influence (reported by 17). These participants see the studied online environment as an opportunity for having an influence and communicating their own opinion. This opportunity in turn is reported to motivate an increase in political engagement. However, several of the participants reported that such an increase in their political engagement presupposed an active engagement from central party members and politicians in the studied online environment. 
Table 2. Example participant comments on how the studied online environment could increase their political engagement

\begin{tabular}{|c|c|}
\hline Theme & Example comments \\
\hline $\begin{array}{l}\text { 1. Sense of } \\
\text { influence }\end{array}$ & $\begin{array}{l}\text { By this I mean that it is possible for me to reach out with my } \\
\text { opinions to a wider audience, I have on several occasions } \\
\text { received "likes" on my comments and to me this is motivating. } \\
\text { Closeness to the power-provided that the comments are read } \\
\text { by someone in charge. Share experiences from the real world. }\end{array}$ \\
\hline $\begin{array}{l}\text { 2. Access to } \\
\text { debate }\end{array}$ & $\begin{array}{l}\text { It is easier to get an interest in particular issues if you have an } \\
\text { arena for speaking out. } \\
\text { I have just discovered political blogs, it is a new arena for me. } \\
\text { Otherwise, I am engaged in political discussions at work and } \\
\text { would like to be more engaged in other (non-political) } \\
\text { organizations. }\end{array}$ \\
\hline $\begin{array}{l}\text { 3. Getting } \\
\text { updated }\end{array}$ & $\begin{array}{l}\text { The website keeps me updated at all times, and keeps my } \\
\text { engagement up. [...] } \\
\text { I think this gives me the opportunity to follow what is going on } \\
\text { [...] }\end{array}$ \\
\hline $\begin{array}{l}\text { 4. Lowered } \\
\text { threshold for } \\
\text { participation }\end{array}$ & $\begin{array}{l}\text { [...] I can participate more actively in discussion where the } \\
\text { topic engages me. } \\
\text { People spend A LOT of time in front of their computers every } \\
\text { day. If we are to have politically active citizens, it must be } \\
\text { easier to participate in the political debates. We achieve this } \\
\text { through [the studied online environment] and the newspaper } \\
\text { comment fields, etc. }\end{array}$ \\
\hline $\begin{array}{l}\text { 5. Local } \\
\text { participation }\end{array}$ & $\begin{array}{l}\text { That I get sufficiently engaged to associate myself with a local } \\
\text { party body, start going to meetings and participate. } \\
\text { [...] A lot of members today hold valuable competency and I } \\
\text { believe that many virtual discussions, between two-three } \\
\text { members, may lead to meetings in local party bodies. }\end{array}$ \\
\hline $\begin{array}{l}\text { 6. Information } \\
\text { on events }\end{array}$ & $\begin{array}{l}\text { Issues that are discussed and meetings that are announced will } \\
\text { contribute to other activities. [...] } \\
\text { Information on seminars and campaigns, as well as other } \\
\text { events, that I primarily see on [the studied online environment]. } \\
\text { [...] }\end{array}$ \\
\hline
\end{tabular}


2. Access to debate (reported by 14). These participants described the access to debate, made possible by the studied online environment in particular or by the general increase in arenas for online political debate, as engaging and inspiring in itself. Three of the participants noted that the discussions in the studied online environment could also serve as a basis for political debate outside this environment. Three explained that the main value of online arenas for political debate is to increase the transparency in political processes and to support grassroots movements.

3. Getting updated (reported by 5). These participants reported that the studied online environment helped them to get updated on political issues. Three of these specifically associated such updates with engagement in political activity. The described updates concerned, for example, general political trends, particular topics under debate, and news concerning particular persons.

4. Lowered threshold for participation (reported by 4). These participants reported that the studied online environment represents a low-threshold offer for persons who want to engage politically, and that it makes it easier to be politically active.

5. Local participation (reported by 4). These participants reported that their activity in the studied online environment could motivate them to participate actively in local politics.

6. Information on events (reported by 4). The studied online environment is used for spreading information on events such as meetings, seminars, and campaigns. Some of the participants reported that such information increases their chances for participating in the events.

See Fehler! Verweisquelle konnte nicht gefunden werden. for example participant comments concerning how the studied online environment could make them more politically active.

\section{Discussion}

In this section, we will first discuss our findings relative to the two main research questions. Then we will discuss the limitations of the study and suggest future work.

\subsection{Motivators for Online Political Debate}

The participants' responses provided relevant insights into possible motivators for participation in online political debate. We find it consoling that the most frequently reported motivator was an engagement in the discussed topic, and that the second most frequent motivator was a wish to contribute in the debate. Both these motivators are in compliance with the ideals of online deliberation. It is useful for developers and hosts of online environments for political debate to know that engaging topics and a wish to contribute may be key motivators for online debaters. In particular, this may have implications for how topics should be presented and moderated. Given that the findings are general, developers and hosts of such online environments needs to look 
for topics and content triggering the participants' engagement, and present topics in an engaging manner, rather than, for example, just present content for informational purposes. It may also be important to strengthen participants' opportunities for making contributions that may actually impact political policymaking, thereby "situating citizens as agents within the policymaking process" [11, p. 182].

That said, it is noteworthy that general frustration was the third most frequently reported motivation to make comments in the online environment. While frustration may possibly help people get started in online debate, such motivation is hardly an optimal basis for the rational-critical discourse of deliberative democracy [2]. Possibly, debaters venting their frustration online may be the reason why some of the study participants criticize what they perceive as disrespectful treatment of others in the debates. Although political debate may benefit from having nerve and temperature, it is an important challenge for the hosts of online political debate to reduce the effect of online debaters motivated mainly by their frustration. In particular, this is important in cases such as the one in this study, where frustration only motivates a small proportion of the online debaters.

Finally, it may be noted that there still is a way to go before online deliberation [2] is the backbone reflex of the participants in the studied online environment. Only two participants reported reciprocal learning as their motivation. Being engaged and wanting to contribute are indeed necessary requisites for online political debate. However, in terms of online deliberation, it will also be necessary to listen to others' perspectives and appreciate the possible learning that may come out of the political debate.

\subsection{Impact on General Political Engagement}

From the existing literature we know that participation in online political debate is highly correlated with general political engagement $[15 ; 1 ; 18]$. Furthermore, online deliberation may strengthen political efficacy and willingness to participate in politics [9].

In our study, the majority of the participants reported that their participation in online political debate might strengthen their political engagement. This finding is in line with Min's conclusion that online deliberation may increase political efficacy and willingness to participate in politics [9]. Furthermore, our findings indicate how such increased willingness to engage politically may be explained.

The most frequently reported reason for a strengthened political engagement is the perceived promise of influence associated with an online environment hosted by a political party. This perceived promise may be strengthened by politicians and central party members participating in the same environment. However, although party members indeed were present as debaters, several of the survey participants voiced concern that central party members and politicians were not more active. This concern reflects a scalability-challenge in the interchange between politicians and ordinary citizens in online political debate; as the number of active debaters increases, it will be next to impossible for central party members and politicians to follow up all comments. 
Consequently, we need sustainable approaches to support interaction between politicians, central party members, and ordinary citizens in online political debates. One approach may be to clarify the promise of the online political debate: that the online environment is an arena for debate mainly among citizens and local party members; however, central party members and politicians may be active to the extent possible. A second approach may be to conduct regular summaries of the content of political debate, for example as input in political policymaking, and be clear on how the online debaters have contributed to the summaries.

Other reasons for strengthened political engagement included the motivation for involvement in local politics, and an increased awareness of political events. Political parties hosting online environments for political debate may benefit from these effects of the online political debate by making easily available offerings to the online debaters, for example by promoting selected offline political events.

\subsection{Limitations and Future Research}

This study was conducted in an online environment for political debate where ordinary citizens, party members and politicians participated. Furthermore, the online environment was designed to foster contemplative comments rather than a fast-paced exchange of messages. Consequently, the generality of our findings is limited to contexts for online political debate that share these characteristics. Future work comparing the kind of online environment used in this study to other online environments for political debate is needed to make more general claims.

The case of the present study was arguably a suitable object of study for our research questions, in particular as Norway is an egalitarian society with high Internet penetration and online maturity in the population. However, the generality of the findings may depend on the characteristics of the society in which the study was conducted. Consequently, it will be beneficial to replicate the study in other cases, preferably in other countries.

Acknowledgement. This work was conducted as part of the research project NETworked Power (http://networkedpower.origo.no) supported by the Norwegian Research Council VERDIKT programme, project number 193090.

\section{References}

1. Conroy, M., Feezell, J.T., Guerrero, M.: Facebook and political engagement: A study of online political group membership and offline political engagement. Computers in Human Behavior 28, 1535-1546 (2012)

2. Dahlgren, P.: The Internet, public spheres, and political communication: Dispersion and deliberation. Political Communication 22, 147-162 (2005)

3. Dahl, R.A.: Democracy and its critics. Yale University Press (1989)

4. Dean, H.: Wikipartia. How the web is restoring democracy to politics. Forbes 179, 94-98 (2007)

5. DeWolfe, C.: The MySpace Generation. Fortune 179, 72-74 (2007)

6. Ezzy, D.: Qualitative analysis. Routledge (2002) 
7. Kahn, R., Kellner, D.: Virtually Democratic: Online Communities and Internet Activism. In: Barney, D., Feenberg, A. (eds.) Community in the Digital Age: Philosophy and Practice, pp. 183-200. Rowman \& Littlefield (2004)

8. Lüders, M.H., Følstad, A., Waldal, E.: Expectations and experiences with MyLabourParty: From right to know to right to participate? Journal of Computer-Mediated Communication (forthcoming)

9. Min, S.: Online vs. face-to-face deliberation: Effects on civic engagement. Journal of Computer-Mediated Communication 12, article 11 (2007)

10. Sevland, L.J., Berg, D.H., Brosvik, T., Kvaløy, O.A., Moe, B.T., Myrvold, T.M., et al.: Det lokale folkestyret i endring? Om deltaking og engasjement i lokalpolitikken. Departementenes Servicesenter (2006)

11. Stromer-Galley, J., Wichowski, A.: Political Discussion Online. In: Consalvo, M., Ess, C. (eds.) The Handbook of Internet Studies, pp. 168-187. Wiley-Blackwell (2011)

12. Teorell, J.: Political participation and three theories of democracy: A research inventory and agenda. European Journal of Political Research, 787-810 (2006)

13. Valenzuela, S., Kim, Y., de Zúñiga, H.G.: Social networks that matter: Exploring the role of political discussion for online political participation. International Journal of Public Opinion Research 24, 163-184 (2012)

14. Verba, S., Nie, N.H.: Participation in America: Political democracy and social equality. Harper \& Row (1972)

15. Vesnic-Alujevic, L.: Political participation and web 2.0 in Europe: A case study of Facebook. Public Relations Review, 466-470 (2012)

16. Vitale, D.: Between deliberative and participatory democracy: A contribution on Habermas. Philosophy \& Social Criticism 32, 739-766 (2006)

17. West, D.M.: Digital government: Technology and public sector performance. Princeton University Press (2005)

18. de Zúñiga, H.G., Jung, N., Valenzuela, S.: Social media use for news and individuals' social capital, civic engagement and political participation. Journal of Computer-Mediated Communication 17, 319-336 (2012) 